\title{
Analysis of Financial Distress in Measuring Bankruptcy Before and After The Covid-19 Pandemic
}

\author{
Supitriyani' ${ }^{1}$, Yansen Siahaan ${ }^{1}$, Astuti' ${ }^{1}$, Juan Anastasya Putri' ${ }^{1}$, Elly Susanti1 \\ ${ }^{1}$ Accounting Departement, Sekolah Tinggi Ilmu Ekonomi Sultan Agung, Indonesia
}

\begin{abstract}
The increasing spread of the Covid-19 virus at this time has forced several company sectors to experience setbacks in their operations. This epidemic has had a major impact, especially on the Transportation SubSector Companies because they have to make some adjustments to government regulations such as implementing health protocols and physical restrictions on travel to break the chain of virus spread. The regulation has an impact on the company's revenue decline and the potency to suffer losses that can result in bankruptcy. This study aims to determine the bankruptcy prediction of the Transportation Sub-Sector Companies listed on the IDX before and after the covid-19 pandemic and to find out the most accurate method. The sampling technique used was non-probability sampling with the purposive sampling technique. The method used is descriptive with a quantitative approach. The results of the hypothesis test show that there are differences in predictions between the Altman and Springate models in predicting bankruptcy before and after the covid-19 pandemic. The Altman model is the most accurate prediction with an accuracy rate of $85.75 \%$, while the Springate model has an accuracy rate of $73 \%$. The study focused on companies listed on the IDX and used two bankruptcy measurement models, so researchers are next expected to use the entire company and other existing bankruptcy prediction, models. In addition, some factors beyond the control of researchers, such as economic conditions that cannot be measured. The renewal of previous research is to use two methods of prediction of bankruptcy, different objects, and research time (before and after the covid-19 pandemic).
\end{abstract}

Keywords: Financial Distress, Altman, Springate

This is an open access article under the CC-BY-NC license

\section{INTRODUCTION}

The increasing spread of the covid-19 virus is currently making some sectors of the company have to experience setbacks and limitations in operating. This is very impactful, especially for companies that are directly involved in the community. One company that directly interacts with consumers is the Transportation Sub-Sector Company. Companies in the Transportation Sub-Sector must make some adjustments to government regulations in carrying out their operational activities during pandemics, such as implementing health protocols and physical and travel restrictions to break the chain of the spread of the virus. The regulation will certainly have an impact on people's interest in using transportation services. The decline in public interest caused GDP growth in the transportation sector to experience very deep pressure. In the second quarter of 2020 , there was a decrease of $-30.84 \%$, while in the third quarter of 2020 , there was a decrease of $-16.70 \%$, which actually increased from the previous quarter. The contraction of growth in the third quarter of 2020 was not as deep as in the second quarter of 2020 due to the adaptation of new habits or the easing of PSBB that improved the performance of transportation 
business fields (Jonathan, 2020). The following presented a graph of the movement of people in using transportation services that have an impact on GDP in transportation sector companies.

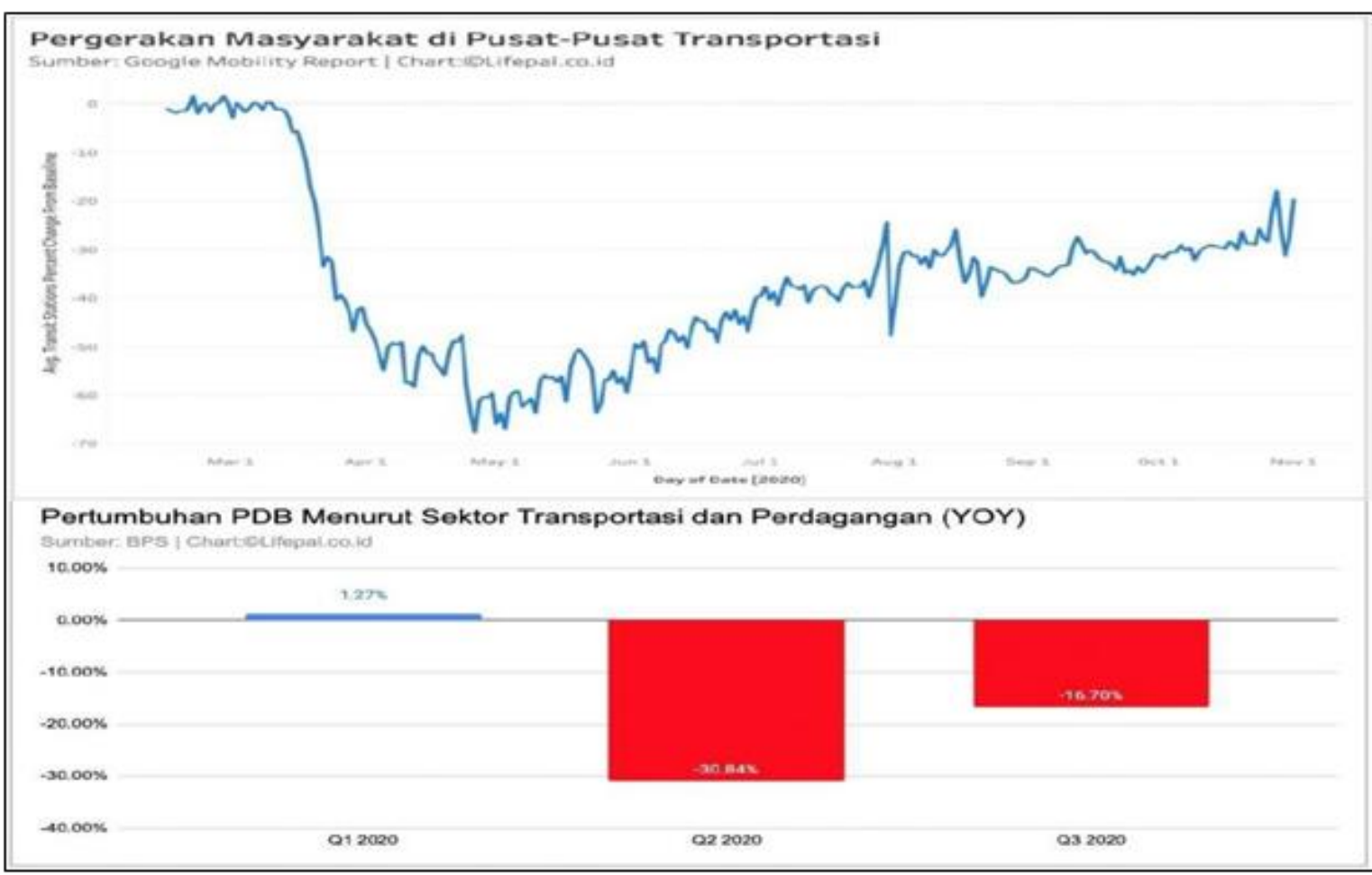

Figure 1. Community Movement in The Centers of Transportation and GDP Growth in the Transportation and Trade Sector

Source : (Jonathan, 2020)

The graph above shows that the movement of people after March continues to decline to its lowest point in May 2020. After May 2020, the movement of people began to increase but still did not return to normal due to various restrictions on social activities. The decrease in public interest in using transportation certainly makes the company's revenue decrease so that it has the potential to experience losses that can result in bankruptcy. This is also supported by a statistical report published on the Indonesia stock exchange; some of the company's shares that experienced turmoil after the covid 19 pandemic were highest in Infrastructure, Utilities, and Transportation Companies, which decreased by $28.55 \%$ which was followed by Trade, Service and Investment Companies which decreased by $17.32 \%$. Therefore, the authors are interested in conducting in-depth research on Transportation Sub-Sector Companies to find out the prediction of bankruptcy before and after the covid-19 pandemic and find out the most accurate methods to measure bankruptcy between Altman and Springate models.

\section{Previous Research}

(Sudrajat \& Wijayanti, 2019) conducted research entitled "Analysis of Bankruptcy Prediction (Financial Distress) By Comparison of Altman, Zmijewski and Grover Models". The results of his research showed that there is a difference in predictions between the Altman (Z-Score), Zmijewski (X-Score), and Grover (G-Score) models in predicting the bankruptcy (financial distress) of basic industrial and chemical sector manufacturing companies listed on the Indonesia Stock Exchange for the period 2015-2018. Grover 
model (G-Score) became the most accurate prediction model with an accuracy rate of $85.14 \%$. The Altman (Z-Score) model has an accuracy rate of $77.70 \%$ and the Zmijewski model (X-Score) at 79.73\%.

(Purnomo \& Hendratno, 2019) conducted research entitled "The Analysis of The Bankrtuptcy With Altman Z- Score Model, Grover, And Zmijewski at Oils Companies Listed In Indonesia Stock Exchange Period 2013-2017". The results of his research showed that there was a difference in the analysis of the revival between the Altman Z-Score, Grover, and Zmijewski methods in oil and gas subsector companies in the period 2013 and 2017. Judging from the accuracy, Zmijewski's method became the most accurate method, with an accuracy rate of $82.5 \%$ and a type error of $17.5 \%$. Furthermore, the most accurate method after that is Grover, who is with an accuracy rate of $80 \%$ and type error of $20 \%$. And the last method with the lowest accuracy is Altman Z-Score which is $37.5 \%$ with a type error of $62.5 \%$.

(Sumarna et al., 2020) conducted research entitled "Analysis of Altman, Zmijewski, Springate and Grover Bankruptcy Prediction Models on Chemical Sub-Sector Manufacturing Industry Listed in IDX 2013 - 2018". The results of his research showed that Zmijewski and Grover's Prediction Model is the most accurate prediction model according to accuracy level testing using two approaches, namely the comparison approach of calculation scores of the 2013 - 2018 research period with the period calculation score $(t+1)$ after the research period (2019) and the prediction model score comparison approach that is associated with the auditor's opinion results contained in each company's financial statements.

(Saputri \& Krisnawati, 2020) conducted research entitled "Comparative Analysis of Modified Altman Z-Score, Springate, Zmijewski, Bankometer, Grover, and RGEC Models for Financial Distress Prediction". The comparison of the results of the analysis of all models showed that the Modified Altman Z-Score, Springate, and Zmijewski models have the same analytical results that all the analyzed samples were included in the distressed category. In addition, the Bankometer, Grover, and RGEC models also have similarities in the results of their analysis, which overall the models analyzed the samples into the non distress category; therefore, these results contradicted the results of the analysis of the 3 previous models.

\section{LITERATURE REVIEW}

\section{Financial Distress}

Financial distress is a way that companies can use in detecting bankruptcy early. Financial distress is also a condition where the company's finances are in an unhealthy state or a crisis that will lead to bankruptcy if not immediately addressed. (Sidabalok Lisnawati et al., 2019). Menurut (Hanafi, 2016) Financial distress is a continuum condition ranging from mild financial difficulties (such as liquidity problems) to more serious financial difficulties, namely not solvable (greater debt compared to assets). One form of failure that occurs in a company that causes bankruptcy is a financial failure. Therefore, financial distress can be interpreted as a situation where the company is experiencing financial difficulties, so that financial distress is defined as a condition when the company can no longer meet obligations to third parties. (Maimunah \& Ali Kesuma, 2020).

Some of the things that can lead to a company's bankruptcy are (Dewi Utari et al., 2016) poor managerial ability, inability to manage the market, inability to manage production processes, inability to manage finances, inability to provide retained earnings, and companies unable to meet working capital needs and unable to hold business expansion. (Syahyunan, 2015), Assessing the level of financial difficulty and predicting the potential for bankruptcy in a company, there are four models, namely the Altman ZScore model, Grover model, Springate model, and Zmijewski model. In this study, the bankruptcy analysis model used is the Altman and Springate models. 


\section{Altman Model (Z-Score)}

(Rudianto, 2013) The Z-Score analysis is a method of predicting the survival of a company by combining several common financial ratios and giving different weights to each other. That means that the Z-Score method can predict the possibility of bankruptcy of a company. Financial distress parameters in this model are networking capital and total assets (X1), retained earnings and total assets (X2), EBIT and total assets (X3), share acquisition value and total liability book value (X4), as well as sales and total assets (X5). The standard Z-Score scoring standard is Z $>2.6=$ Safe Zone, $1.1<\mathrm{Z}<2.6=$ Gray Zone and $\mathrm{Z}<1.1=$ Dangerous Zone with the following formula: $\mathrm{AZ}=0,717 \mathrm{X} 1+0,087 \mathrm{X} 2+3,107 \mathrm{X} 3+0,420 \mathrm{X} 4+0,998 \mathrm{X} 5$

\section{Springate Model (Springate Score)}

(Rudianto, 2013) Springate Score is a method of predicting the survival of a company by combining several common financial ratios with different weights from each other. The financial distress parameters in this model are networking capital and total assets (X1), EBIT and total assets (X2), EBIT and total current liabilities (X3), as well as sales and total assets (X4). The rating standard in the Springate Score formula is $\mathrm{Z}>0.862=$ healthy company and $\mathrm{Z}<0.862=$ potentially bankrupt company. The Springate Score formula for different types of companies, is as follows: $\mathrm{Z}=1,03 \mathrm{X} 1+3,07 \mathrm{X} 2+0,66 \mathrm{X} 3+0,4 \mathrm{X} 4$

\section{Accuracy Level}

To find out the level of accuracy and Type Error in all three methods (Rizkyansyah \& Laily, 2018), Then use the formula as follows:

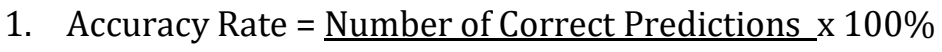
Number of samples

2. Type Error $=\underline{\text { Number of Wrong Predictions } \times 100 \%}$ Number of samples

\section{RESEARCH METHOD}

\section{Data Collection Techniques}

The data collection technique used is a documentation technique. This documentation technique is done by searching for data through books, financial statements, journals, previous research, electronic media such as stock exchange websites, and research object websites.

\section{Population and Sample}

The population in this study is all companies listed on the Indonesia Stock Exchange as companies engaged in the Transportation Sub-Sector before and after covid-19 period 2019-2020. The number of companies that became the population in this study there were as many as 46 companies. The sampling technique is done using non-probability sampling with purposive sampling techniques so that 28 companies are obtained.

\section{Data Analysis Techniques}

The data analysis techniques used are qualitative descriptive analysis techniques and comparative analysis techniques. Qualitative descriptive analysis was conducted to look at the picture of financial distress in the Transportation Sub-Sector before and after covid-19 period 2019-2020, while comparative analysis was conducted to find out the right method to measure the level of financial distress in the 
Transportation Sub-Sector before and after covid-19 period 2019-2020 as measured using the Altman and Springate models.

\section{FINDINGS AND DISCUSSION}

\section{Descriptive Statistical Results}

The results of this descriptive statistical test of the researcher can be presented in Table 1.

Table 1. Descriptive Statistics

\begin{tabular}{lllcc}
\hline & N & Min & Max & Mean \\
\hline Altman & 56 & $-13,956$ & 3,775 & $-0,588$ \\
Springate & 56 & $-0,898$ & 3,206 & 0,709 \\
N & 56 & & & \\
\hline
\end{tabular}

Source: Processed data, Microsoft Excel, 2021

Based on descriptive statistical tests conducted, the minimum value of the Altman model is -13,956 in BLTA companies in 2020. This indicates the company is in a dangerous zone because the value is smaller than 1.1. The maximum value of the Altman model is 3.775 in rigs companies in 2020, while the average value of the Altman model is -0.588 , which indicates that the company is in a dangerous zone because the value is smaller than 1.1.

For the Springate model, the minimum value obtained is -0.898 in TAXI companies in 2020, which indicates that the company is potentially bankrupt because the value is smaller than 0.862 . For the maximum value of the Springate model, the value of 3,206 was obtained by ZBRA in 2019. This indicates that the company is healthy because the value of the Springate score is greater than 0.862 . The average value of the Springate model obtained a value of 0.709 . It states that the company experienced a potential bankruptcy because the value of the Springate score is smaller than 0.862 .

\section{Accuracy Calculation}

In the calculation of accuracy, it is necessary to know in full the data related to the calculation of financial distress by using the Altman and Springate models in transportation sub-sector companies that can be seen in Table 2 .

Table 2. Altman and Springate Model Calculation Results

\begin{tabular}{ccccccccc}
\hline & \multicolumn{3}{c}{ Altman (Z-Score) } & \multicolumn{5}{c}{ Springate (S-Score) } \\
\hline \multirow{2}{*}{ KODE } & $\begin{array}{c}\text { Z Score } \\
\mathbf{2 0 1 9}\end{array}$ & Ket. & $\begin{array}{c}\text { Z Score } \\
\mathbf{2 0 2 0}\end{array}$ & Ket. & $\begin{array}{c}\text { S Score } \\
\mathbf{2 0 1 9}\end{array}$ & Ket. & $\begin{array}{c}\text { S Score } \\
\mathbf{2 0 2 0}\end{array}$ & Ket. \\
\hline ASSA & 0.739 & B & 0.792 & B & 0.677 & B & 0.738 & B \\
BBRM & -0.226 & B & 0.027 & B & -0.221 & B & 0.282 & B \\
BIRD & 1.055 & B & 0.567 & B & 0.839 & B & 0.062 & B \\
BLTA & -13.443 & B & -13.956 & B & 0.376 & B & 0.384 & B \\
BULL & 0.760 & B & 0.904 & B & 0.652 & B & 0.608 & B \\
CANI & -1.304 & B & -2.365 & B & 1.215 & TB & 1.731 & TB \\
CMPP & 2.757 & GA & -2.896 & B & 1.798 & TB & 0.537 & B \\
GIAA & 0.804 & B & -0.446 & B & 1.275 & TB & 0.109 & B \\
HITS & 1.083 & B & 0.857 & B & 0.914 & TB & 0.798 & B
\end{tabular}


Journal of Governance Risk Management Compliance and Sustainability (JGRCS), Vol. 1 (1), 53-60

Analysis of Financial Distress in Measuring Bankruptcy Before and After The Covid-19 Pandemic Supitriyani, Yansen Siahaan, Astuti, Juan Anastasya Putri, Elly Susanti

\begin{tabular}{ccccccccc}
\hline & \multicolumn{3}{c}{ Altman (Z-Score) } & \multicolumn{5}{c}{ Springate (S-Score) } \\
\hline \multirow{2}{*}{ KODE } & $\begin{array}{c}\text { Z Score } \\
\mathbf{2 0 1 9}\end{array}$ & Ket. & $\begin{array}{c}\text { Z Score } \\
\mathbf{2 0 2 0}\end{array}$ & Ket. & $\begin{array}{c}\text { S Score } \\
\mathbf{2 0 1 9}\end{array}$ & Ket. & S Score & Ket. \\
\hline IATA & 0.585 & B & -0.350 & B & 0.355 & B & 0.468 & B \\
INDX & 1.830 & GA & 1.473 & B & 0.374 & B & 0.195 & B \\
KARW & -4.151 & B & -3.947 & B & 2.672 & TB & 2.702 & TB \\
LEAD & -0.046 & B & 0.029 & B & -0.261 & B & -0.217 & B \\
LRNA & 2.364 & GA & 1.186 & B & 0.271 & B & -0.522 & B \\
MBSS & 1.401 & B & 1.124 & B & 0.553 & B & 0.151 & B \\
MIRA & 2.301 & GA & 2.269 & GA & 0.343 & B & 0.084 & B \\
NELY & 2.558 & GA & 2.274 & GA & 2.109 & TB & 1.888 & TB \\
PTIS & 0.945 & B & 0.884 & B & 0.727 & B & 0.619 & B \\
RIGS & 1.291 & B & 3.775 & TB & 0.669 & B & 0.519 & B \\
SDMU & 0.398 & B & -0.279 & B & 0.568 & B & 0.895 & TB \\
SMDR & 1.281 & B & 1.287 & B & 1.250 & TB & 1.006 & TB \\
SOCI & 0.749 & B & 1.124 & B & 0.542 & B & 0.812 & B \\
TAXI & -4.372 & B & -7.070 & B & -0.210 & B & -0.898 & B \\
TMAS & 0.666 & B & 1.051 & B & 0.716 & B & 0.571 & B \\
TPMA & 1.515 & B & 1.427 & B & 1.033 & TB & 0.846 & B \\
WEHA & 0.961 & B & -0.034 & B & 0.629 & B & -0.484 & B \\
WINS & 0.204 & B & 0.289 & B & -0.001 & B & -0.209 & B \\
ZBRA & -13.324 & B & -12.324 & B & 3.206 & TB & 2.954 & TB \\
\hline
\end{tabular}

Source: Processed data, 2021

Based on the results of calculations from the Altman Model during the year period studied there were 48 companies with Z-score values categorized as bankrupt, 1 company with A Z-score categorized as not bankrupt and 7 companies with Z-score values categorized as grey areas, from the results obtained can be calculated the accuracy level of the Altman Model used is:

Accuracy $=48 / 56 \times 100 \%=85.7 \%$

The calculation results of the Springate Model there are 41 S-score values categorized as bankrupt and $15 \mathrm{~S}$-score values that are categorized as not bankrupt, then from the results can be calculated the accuracy rate of the Springate Model used:

Accuracy $=41 / 56 \times 100 \%=73 \%$

A comparative percentage in such methods for measuring bankruptcy rates in the Transportation Sub-Sector Companies can be presented in Table 3.

Table 3. Percentage Rate Comparison of Altman Z-Score and Springate Score

\begin{tabular}{lcc}
\hline \multirow{2}{*}{ Category } & \multicolumn{2}{c}{ Percentage of Two Methods } \\
\cline { 2 - 3 } & Altman Z-Score & Springate Score \\
\hline Safe Zone & $1,80 \%$ & $27,00 \%$ \\
Gray Zone & $12,50 \%$ & - \\
Dangerous Zone & $85,70 \%$ & $73,00 \%$ \\
\hline
\end{tabular}


Source: Processed data, 2021

From Table 3 it can be known that both methods provide varying percentage rates. The difference in calculation results of each method is due to the cut-off value and the variable calculation components that vary between the methods. The average comparison of the two methods, the Altman Z-Score and Springate Score methods, shows that the company is experiencing a dangerous zone, and if this continues, it does not rule out the possibility that this company will potentially go bankrupt. This should be a concern for all stakeholders from both company management and investors to find good solutions to improve the company's operational performance.

The Altman Z-Score method provides a bankruptcy measurement rate of $85.70 \%$, while the Springate Score method is 73\%. Overall it can be concluded that the Springate Z-Score method results in a fairly low percentage of bankruptcy measurements when compared to the Altman Score method. It can be concluded that the right method for measuring the bankruptcy rate in the Transportation Sub-Sector Company is the Altman Score method because the percentage rate in the safe zone is lower and in the dangerous zone is higher than other methods. The results of this study are different from the results of the study (Sudrajat \& Wijayanti, 2019), (Purnomo \& Hendratno, 2019), (Sumarna et al., 2020), and (Saputri \& Krisnawati, 2020) Grover and Zmijewski's model is more accurate at predicting bankruptcy.

\section{CONCLUSION}

The results of the hypothesis test showed that there was a difference in predictions between altman and springate models in predicting the bankruptcy (financial distress) of transportation sub-sector companies listed on the Indonesia Stock Exchange before and after the covid-19 pandemic. The Altman model became the most accurate prediction model with an accuracy rate of $85.75 \%$, while the Springate model had an accuracy rate of $73 \%$. Thus it can be stated that the Altman Model is more accurate in analyzing financial distress before and after the covid-19 pandemic in Transportation Sub-Sector Companies listed on the Indonesia Stock Exchange.

The study focused only on companies listed on the IDX and used two bankruptcy, measurement models. Therefore, researchers are then expected to use all existing companies, both overseas companies, and compare companies that are still listing with delisting companies and can use other bankruptcy prediction models such as Ohlson, Fulmar, Shirata, Zavgren, and Taffler models. In addition, there are several factors beyond financial ratios that are beyond the control of researchers, such as economic conditions (inflation, unemployment rate, economic growth, technology, culture, and others) that cannot be measured.

The update of previous researchers is that this study uses two methods of bankruptcy prediction, different research objects, and research time conducted before and after the covid-19 pandemic that is still relevant today, so it is very beneficial for investors in making decisions when to make investments in the future.

\section{ACKNOWLEDGMENT}

The research team thanked either the research funder, the support of the facility, or the help of manuscript reviews. The researcher thanked the accounting lecturers and the Ministry of Ristekdikti, who had financed this research from start to finish, to LPPM Sultan Agung College of Economics, who had facilitated the team in conducting the research. This research is the result of the Research Grant of Beginner Lecturer Kemenristek Dikti. 


\section{REFERENCES}

Dewi Utari, Purwanti, A., \& Prawironegoro, D. (2016). Management Accounting: Practical Approach (4th ed.). Mitra Wacana Media.

Hanafi, M. M. (2016). Financial Management (2nd ed.). BPFE-Yogyakarta.

Jonathan, A. (2020). Transportation company's stock performance also fell in the hit by the Covid19 pandemic? Zonautara.Com, 1. https://zonautara.com/2020/11/12/performa-saham-perusahaantransportasi-turut-rontok-dihantam-pandemi-covid-19/

Maimunah, \& Ali Kesuma. (2020). Accuracy of Zmijewski and Grover Models in Predicting Financial Distress Financial Distress. 01(02), 1-6.

Purnomo, A. F., \& Hendratno, H. (2019). Analysis of Bankruptcy Prediction Using Altman Z-Score, Grover, and Zmijewski Methods on Oil and Gas Companies Listed on the Indonesia Stock Exchange For the Period 2013-2017. EProceeding of Management, 6(2), 2143-2148.

Rizkyansyah, K., \& Laily, N. (2018). Measurement of Health Levels and Symptoms of Financial Distress With Springate, Zmijewski, dan Grover Methods. Jurnal Ilmu dan Riset Manajemen (JIRM), 7(8), 1-14.

Rudianto. (2013). Management Accounting (1st ed.). Erlangga.

Saputri, H. A., \& Krisnawati, A. (2020). International Journal of Multicultural and Multireligious Understanding Comparative Analysis of Modified Altman Z-Score, Springate, Zmijewski, Bankometer, Grover, and RGEC Models for Financial Distress Prediction ( Empirical Study in Banking Companie. International Journal of Multicultural and Multireligious Understanding, 260-278.

Sidabalok Lisnawati, E., Deviyanti Risma, D., \& Ginting, Y. L. (2019). Financial Ratio in Predicting The $\begin{array}{lllll}\text { Bankruptcy of Coal } & \text { Mining (2). }\end{array}$ https://pdfs.semanticscholar.org/100e/56b8d5aa80e86d1c85f70271cc37d628fc6a.pdf

Sudrajat, M. A., \& Wijayanti, E. (2019). Analysis of Bankruptcy Prediction (Financial Distress) By Comparison of Altman, Zmijewski and Grover Models. Journal of Accounting, 3(2), 166-174

Sumarna, E., Yazid, H., \& Ichwanudin, W. (2020). Analysis of Bankruptcy Prediction Models Altman, Zmijewski, Springate and Grover on Industrial Manufacturing Sub-Chemical Sub-Sector Listed In IDX Year 2013 - 2018. 4(2), 109-122.

Syahyunan. (2015). Financial Management Planning, Analysis, and Financial Control (2nd ed.). USU Press. 